\title{
AKUNTANSI DAN KAPITALISME
}

\author{
Helmy Adam \\ Fakultas Ekonomi Universitas Brawijaya Malang \\ Jl. MT. Haryono No. 165, Telepon 085646447369
}

\begin{abstract}
Accountancy can form and be formed by environment where about the accountancy developed. Accountancy expanding in this time is notching from capitalism ideology. Capitalism born from rational values, liberalism values, and materialism values with understanding assuming society prosperity will only be obtainable production is well delivered to every individual giving infinite facility for resources management in reaching target. This artcle aim at, providing conventional description accountancy ideology influencing theoretical concept forming accountancy.
\end{abstract}

Keywords: accountancy, ideology, capitalism

Kapitalisme, yang menyerukan suatu ideologi dengan tema liberalisme dan demokrasi, dibangun atas materialisme abad 18, dan menyusun ideologinya dengan menyerap kebebasan humanisme, filsafat, sains dan peradaban yang juga mirip dengan borjuisme modern (Syariati 1996, 82), pandangan kapitalisme pada dasarnya bersumber dan berakar pada pandangan filsafat ekonomi klasik, terutama ajaran Adam Smith yang dituangkan dalam karyanya Wealth of Nation (1776). Selain Adam Smith, yang umumnya disebut sebagai tokoh perintis pandangan ekonomi klasik, yaitu David Ricardo dan James Mill yang kesemuanya membangun filsafat pemikirannya di atas pandangan filsafat ekonomi liberalisme. Mereka percaya pada kebebasan individu (personal liberty), pemilikan pribadi (private property) dan inisiatif individu serta usaha swasta (private enterprise) (Fakih 2002, 45-6).

Kapitalisme yang lahir dari paham yang menganggap kemakmuran masyarakat hanya akan dapat diperoleh jika kegiatan produksi diserahkan kepada tiap individu dengan memberi kebebasan yang seluas-luasnya. Jika tiap individu memperoleh kemakmuran maka seluruh masyarakat yang terdiri dari individu-individu juga akan memperoleh kesejahteraan bersama. Hal inilah sebagai pijakan pada filsafat rationalism, liberalism, dan materalism yang membentuk 
kapitalisme. Kapitalisme akan membentuk dan melegitimasi lingkungan yang ada di sekitarnya.

Berdasar kriteria di atas Belkaoui (1985) menjelaskan pendapat Karl Marx bahwa akuntansi ini adalah merupakan bagian dari ideologi kapitalis. Menurutnya akuntansi adalah:

. . . alat untuk melegitimasi keadaan, struktur sosial ekonomi, dan politik kapitalis. Akuntansi merupakan bentuk kesadaran yang palsu yang merupakan alat untuk memistikkan bukan memberikan informasi yang benar tentang hubungan sosial yang membentuk lembaga produksi (Harahap 2001, 11).

Akuntansi yang dibentuk oleh lingkungannya (dalam hal ini ideologi) akan dapat mempengaruhi jiwa dan alur pikir dari akuntansi. Menurut Belkaoui (1985) akuntansi bisa dianggap sebagai suatu ideologi, karena akuntansi dinilai telah menopang atau sebagai subsistem dari ideologi kapitalisme yang mengutamakan kepentingan pihak pemilik modal (Harahap, 1997:28).

Akuntansi sebagai salah satu alat yang memiliki kekuatan untuk menopang kapitalisme serta melegitimasinya. Dengan mengutamakan kekuatan-kekuatan pemilik modal untuk 'mencengkeram' kehidupan ekonomi seluruh masyarakat dengan pengendalian dan pengaturan-pengaturannya.

\section{Faktor Lingkungan Habitat Akuntansi}

Akuntansi sangat berhubungan dengan dengan nilai sosial dan ekonomi yang berlaku dalam masyarakat. Dengan demikian, perubahan dalam sifat akuntansi. Perkembangan kapitalisme melalui perilaku dan ekonomi (akuntansi) mengalami perubahan seiring dengan perubahan peradaban masyarakat mulai dunia kuno (jaman lama) hingga kini (modern).

Perubahan itu terasa, sejak dengan adanya Revolusi Industri di Inggris, di mana ukuran bisnis dan industri bertambah besar. Bisnis skala besar memberikan andil bagi perubahan bentuk organisasi baru. Perkembangan itu memberikan iklim yang baik bagi pertumbuhan kapitalis. Sehingga format dan model akuntansi juga harus menyesuaikan apa yang terjadi pada masa itu. Akuntansi tidak hanya dikembangkan untuk merespons informasi yang dibutuhkan masyarakat, tetapi juga hanyut dalam jiwa kapitalisme (Muhammad, 2002:97). Sehingga para akuntan telah meneliti dan menerapkan berbagai aturan akuntansi yang ada 
dalam kerangka kapitalis, dengan membuat asumsi-asumsi implisit dan semacamnya dibalik konsep akuntansi.

Dalam pandangan ideologi kapitalis sistem ekonomi adalah apa yang membahas tentang kebutuhan-kebutuhan (needs) manusia beserta alat-alat (goods) pemuasnya (an-Nabhani $1990,5)$. Di mana ia sesungguhnya hanya membahas masalah yang menyangkut aspek-aspek yang bersifat materi dari kehidupan manusia. Sedangkan Khan (1989, 23) mengatakan Kapitalisme merupakan suatu bentuk tatanan ekonomi yang digunakan oleh semua masyarakat yang sistem ekonominya terintegrasi dengan sistem pasar. Dengan kata lain kita dapat mengatakan bahwa kapitalisme terbentuk dari pemikiran-pemikiran seperti kepemilikan pribadi, uang, kredit, modal, dan keuntungan yang kemudian di institusikan sehingga mereka menjadi bagian dari sistem ekonomi. Sedangkan Triyuwono (2000) mengungkapkan:

Bila akuntansi dilahirkan dalam lingkungan kapitalistik, maka informasi yang disampaikannya mengandung nilai-nilai kapitalistik. Kemudian keputusan dan tindakan ekonomi yang diambil seseorang yang berdasarkan pada informasi ini juga mengandung nilai-nilai kapitalistik. Akhirnya realitas yang diciptakan adalah realitas kapitalistik. Singkatnya, informasi akuntansi yang kapitalistik akan membentuk jaringan kuasa kapitalistik. Jaringan kuasa inilah yang akhirnya mengikat dan memilin manusia dalam samsara kapitalisme (Triyuwono 2000,8).

Sedangkan menurut Sombart (1919) ada dua karakteristik utama kapitalisme, yaitu: maksimalisasi laba dan tindakan ekonomi yang rasional. Semangat kapitalisme, liberalisme dan maksimasi keuntungan, merupakan bagian dari budaya (manifestasi dari nilai-nilai budaya yang melekat pada kapitalisme) yang berkembang di negara-negara barat. Pada tempat yang sama double entry bookkeeping dikembangkan sebagai suatu teknologi yang menjadi bagian dari kapitalisme itu sendiri. Hal ini lebih ditegaskan oleh Sombart (1919) yang mengatakan :

One cannot imagine what capitalism would be without double-entry book keeping: the two pheno-mena are connected as intimately as form and content. One cannot say whether capitalism created double-entry book keeping as tool its expantion; or whether perhaps, conversely, doubleentry bookkeeping created capitalism (Kam, 1990:23-4).

Hal di atas dipertegas oleh Mathews dan Perera (1993) atas tesis Sombart (1924) bahwa akuntansi dan kapitalisme sangat erat, dia menjelaskan :

One such theory was that put forward by Sombart (1924) who suggested that double entry bookkeeping was such a powerful tool that it led to the development of a new social and economic system which we call capitalism (Mathews and Perera 1993, 15).

Sombart (1924) mempunyai argumen bahwa double entry bookkeeping yang dalam pengembangannya didorong oleh ideologi kapitalisme, karena double entry bookkeeping 
mempunyai dua karakter utama kapitalisme yaitu instrumen mengkalkulasikan laba yang diperoleh dan motif tindakan rasionalisasi ekonomi.

Pengaruh kapitalisme tersebut digunakan dalam format usaha untuk memperoleh laba yang maksimal di mana akuntansi merupakan alat untuk menunjukkan tercapainya tujuan tersebut. Dalam hal ini didukung dengan pendapat Max Weber (1930) mengutarakan pendapatnya bahwa:

The modern rational organization of capitalistic enterprise would not have been possible without two important factors in its development; separation of business from household. . . and, closely connected with it, rational bookkeeping (Kam, 1990:24)

Lebih lanjut seperti yang dikutip oleh Kam (1990, 24), Sombart memberikan dua alasan mengapa double entry bookkeeping mempunyai kontribusi besar dalam pengembangan perusahaan yang kapitalistik.

1. Double entry bookkeeping memungkinkan pemisahan antara pemilik dan kesatuan usaha. Dengan demikian, maka akuntansi akan menjadi fasilitas yang mempermudah pertanggungjawaban kepada pemilik.

2. Dalam kesatuan bisnis dari perkiraan modal (investasi) ke laporan laba rugi, yang menunjukkan ringkasan transaksi yang terjadi sehingga di peroleh nilai laba atau rugi, kemudian kembali pada perkiraan modal lagi.

Dengan demikian konsep pemisahan antara pemilik dan kesatuan usaha sesuai betul dengan konsep entity theory yang menghendaki adanya pemisahan antara satuan usaha dengan pemilik.

\section{AKUNTANSI DAN KAPITALISME}

Akuntansi seolah dua sisi mata uang yaitu selain terbentuk dan berkembang dari lingkungannya, namun juga mempunyai efek mempengaruhi dan membentuk lingkungannya. Akuntansi konvensional yang merupakan satu subsistem dari makro sistem ekonomi kapitalis secara langsung maupun tidak langsung menjadikan kapitalis berkembang dan menempati kemapanan eksistensi seperti sekarang ini. Triyuwono $(1996,44)$ mengemukakan:

Akuntansi sebagaimana dikenal dalam masyarakat umum, adalah suatu media yang disediakan untuk memberikan informasi dari sebuah entitas bisnis bagi pihak-pihak dalam pengambilan keputusan-keputusan ekonomi ... di mana akuntansi mampu 
memberikan kontribusi yang besar bagi perkembangan sistem ekonomi kapitalis (Triyuwono, 1996:44).

Akuntansi dan kapitalisme oleh beberapa ahli sejarah ekonomi telah dikaitkan dengan klaim umum bahwa sistem tatabuku berpasangan (double-entry bookkeeping) merupakan suatu hal yang sangat penting bagi perkembangan dan evolusi kapitalisme. Weber (1930) mengemukakan argumennya, yakni:

Organisasi industrial yang rasional, yang terbiasa dengan pasar teratur, bukannya dengan kesempatan-kesempatan politis atau spekulatif irasional demi mengejar keuntungan, bagaimanapun bukan merupakan satu-satunya ciri kapitalisme Barat. Pengorganisasian secara rasional modern atas usaha kapitalistik tidak akan mungkin terwujud tanpa adanya dua faktor penting dalam perkembangannya: pemisahan bisnis dari rumah tangga yang mendominasi sepenuhnya kehidupan ekonomik modern dan, yang berhubungan erat dengan itu, pembukuan yang rasional ... (Andreski, 1996:22).

Alasan utama untuk itu adalah adanya persyaratan yang tidak bisa ditinggalkan bagi kebebasan ini, yaitu: tata buku bisnis yang rasional dan pemisahan secara legal/sah atas milik usaha dengan milik pribadi/perorangan, sama sekali tidak ada, atau baru saja berkembang. Tesis ini diperluas oleh Sombart (1915) sebagai berikut:

Seseorang tidak dapat membayangkan akan seperti apa kapitalisme tanpa sistem pembukuan berpasangan: kedua fenomena tersebut saling terkait secara intim seperti bentuk dan isi. Seseorang tidak dapat mengatakan apakah kapitalisme menciptakan sistem pembukuan berpasangan sebagai alat dalam ekspansinya; atau mungkin, sebaliknya, sistem pembukuan berpasangan menciptakan kapitalisme (Belkaoui, 2000:12).

Lebih lanjut Belkaoui $(2000,13)$ menjelaskan kaitan antara akuntansi dan kapitalisme ini dikenal dengan tesis Sombart atau argumen Sombart. Tesis ini menunjukkan bahwa tansformasi aset menjadi nilai abstrak dan ekspresi kuantitatif hasil aktivitas usaha, akuntansi sistematik dalam bentuk pembukuan berpasangan memungkinkan: pertama, pengusaha kapitalistik untuk merencanakan, mengatur dan mengukur dampak aktivitasnya; dan kedua, untuk pemisahan pemilik dan usaha itu sendiri, sehingga memungkinkan pertumbuhan korporasi. Empat alasan berikut menurut James O. Winjum (1971) secara umum dikemukakan untuk menjelaskan peran pembukuan berpasangan dalam ekspansi ekonomi yang terjadi setelah abad pertengahan:

1. Pembukuan berpasangan menyumbang sikap baru dalam kehidupan ekonomi. Tujuan pokok perusahaan abad pertengahan yang lama digantikan oleh tujuan kapitalistik untuk memperoleh profit. Semangat akuisisi (spirit of acquisition) dikembangkan dan didorong. Sistem pembukuan berpasangan mengilhami pencarian profit. Tujuan 
perusahaan dapat ditempatkan dalam bentuk yang spesifik dan konsep modal dimungkinkan.

2. Spirit akuisisi yang baru tersebut dibantu dan didorong oleh perbaikan kalkulasi ekonomik. Penggunaan sistem terpadu akun yang saling terkait memungkinkan pengusaha mengejar profit secara rasional. Rasionalisasi sekarang dapat didasarkan pada kalkulasi yang cermat. Kondisi ekonomi sekarang dapat segera ditentukan dan rencana yang rasional untuk operasi masa depan dapat dikembangkan.

3. Rasionalisme baru ini selanjutnya ditingkatkan oleh organisasi yang sistematik. Pembukuan yang sistematik mengembangkan keteraturan dalam akun dan organisasi perusahaan. Sifat yang dualitas memungkinkan pengecekan akurasi; mekanisasi dan objektivitasnya memungkinkan pencatatan kegiatan usaha secara teratur dan berkesinambung. Sistem ini adalah sistem kalsifikasi yang unik.

4. Sistem pembukuan berpasangan memungkinkan pemisahan kepemilikan dan manajemen sehingga mendorong pertumbuhan perusahaan patungan yang besar. Pemisahan aset usaha dan aset pribadi, memungkinkan perusahaan berdiri sendiri (autonomous). Teknik pembukuan berpasangan yang terstandarisasi membuat komunikasi dapat dipahami oleh banyak pihak tidak hanya oleh pemilik yang menjadi pengelola (owner manager) dan pembukuannya (Belkaoui, 2000: 13).

Tesis tersebut tidak mengejutkan, karena diturunkan dari kesimpulan umum pada waktu itu bahwa pertukaran (trade) merupakan konsekuensi alamiah dari pengadopsian sistem tatbuku berpasangan. Apakah sistem berpasangan dalam akuntansi sistematik sangat diperlukan bagi suksesnya perusahaan komersial tidak mudah ditentukan. Meskipun mungkin untuk memperoleh pernyataan-pernyataan tentang keutamaan pembukuan, bukti historis yang disediakan Yamey (1964) mengindikasikan bahwa pengusaha abad ke 16 sampai 18 tidak menggunakan sistem tatabuku berpasangan untuk mengikuti perkembangan profit dan modal, tetapi sekedar sebagai catatan akuntansi. Dia menyatakan:

... Fungsi sistem pembukuan berpasangan tidak lebih dari menyediakan suatu kerangka agar dapat dicocokkan, disusun, dikelompokkan, dan dikelompokkan kembali. Sistem berpasangan tidak dengan sendirinya menentukan rentang data yang harus dimasukkan dalam setting tertentu, tidak juga menentukan pola menentukan pola pengurutan internal dan pengurutan kembali data (Belkaoui, 2000:13).

Selanjutnya dia juga menyatakan bahwa:

1. Pembukuan berpasangan tidak diperlukan untuk menetukan profit dan modal.

2. Pembukuan berpasangan hanya berguna untuk masalah-masalah rutin, dan

3. Pembukuan berpasangan tidak berguna untuk pemilihan peluang yang tersedia bagi pengusaha (Belkaoui 2000, 13) . 
Perbedaan antara Sombart dan Yamey pada dasarnya terletak pada interpretasi atas signifikansi teknik pembukuan berpasangan dan penggunaan awal catatan tatabuku berpasangan.

\section{Implikasi dan Karakteristik Akuntansi yang Dibentuk Kapitalisme}

Pertanda kapitalisme dalam akuntansi yang paling umum menurut Max Weber (1930) adalah perhitungan rasional atas kapital. Perhitungan seperti itu meliputi :

1. Pemilikan semua sarana fisik untuk produksi (tanah, bahan-bahan mentah, mesin, peralatan, dan seterusnya) sebagai milik usaha-usaha industrial swasta otonom yang bisa dijual.

2. Akuntansi melibatkan kebebasan pasar, yaitu tidak adanya pembatasan-pembatasan irasional atas perdagangan. Pembatasan-pembatasan seperti itu mungkin menyangkut halangan-halangan status, bila suatu cara hidup atau konsumsi tertentu ditetapkan bagi suatu kelas, seperti ketika warga kota tidak diijinkan memiliki suatu pertanahan, atau seorang ksatria atau petani tidak diijinkan melakukan suatu pekerjaan.

3. Akuntansi kapitalistik membutuhkan teknologi rasional. Karena dengan rasionalitas akan memudahkan dalam kalkulasi laba dengan meninggalkan faktor-faktor eksternalitas.

4. Bentuk kapitalistik dari organisasi industrial, supaya dapat beroperasi secara rasional, harus didasarkan pada peradilan dan administrasi yang dapat diperhitungkan.

5. Pekerja bebas (rakyat harus tersedia), yang bukan saja orang-orang yang berkesempatan melakukannya secara legal tetapi juga yang karena keadaan ekonomi harus menjual tenaga mereka di pasar, tanpa hambatan-hambatan.

6. Penggunaan secara umum sarana-sarana komersial yang berbentuk hak-hak saham dalam suatu perusahaan bila kekayaan mengambil bentuk surat-surat yang dapat diperjualbelikan (Andreski, 1996:105-6).

Akuntansi secara epistimologi tidak lain adalah produk modernitas yang konsekuensinya, sangat kental dengan nilai-nilai modernisme (teori tradisional) terutama modernisme pencerahan yang positivistik dengan mitos khas: netral, obyektif dan ahistoris (Triyuwono, 1996:54). Nilai-nilai inilah yang sekarang mendominasi akuntansi baik dalam pengertian teori maupun praktik, yang kemudian dikenal dengan sebutan Teori Akuntansi Positif (Positive Accounting Theory atau Mainstream Accounting Theory). 
Oleh karena itu tidaklah mengherankan jika konsep akuntansi yang dihasilkan cenderung berjiwa kapitalistik karena didasari dan diturunkan dari postulat yang dihasilkan dari nilai sosial masyarakat yang berjiwa kapitalistik, hal ini bisa dilihat dari struktur teori akuntansi yang ada (lihat gambar 2).

Harahap (1997) mengungkapkan bahwa:

Struktur teori akuntansi yang menggambarkan susunan, hierarki, dan konsep menyeluruh dari akuntansi keuangan yang akan membantu menyatukan langkah dan pendapat sehingga bermanfaat bagi semua orang untuk meningkatkan kegunaannya. Namun tidak dapat disangkal lagi bahwa struktur teori akuntansi yang dipengaruhi oleh sistem ekonomi, sosial, ideologi yang dianut oleh masyarakat yang ada (Harahap, 1997:59).

Belkaoui $(1999,131)$ memberikan pengertian struktur teori akuntansi konvensional sebagai elemen yang saling berkait yang menjadi pedoman pengembangan teori dan penyusunan teknik-teknik akuntansi. Struktur teori akuntansi menggambarkan susunan, hirarki dari konsep menyeluruh akuntansi keuangan. Namun tidak dapat disangkal lagi bahwa struktur teori akuntansi dipengaruhi oleh sistem ekonomi, sosial, ideologi yang dianut oleh suatu masyarakat. Sehingga jika dilihat pengaruhnya bisa diamati dari hubungan antara pemakai laporan keungan, prinsip akuntansi, teori akuntansi serta fenomena sosial dapat dilihat dari gambar berikut ini :

\section{Gambar: 1.}

Hubungan Pemakai Laporan Keuangan, Teori Akuntansi dan Fenomena Sosial

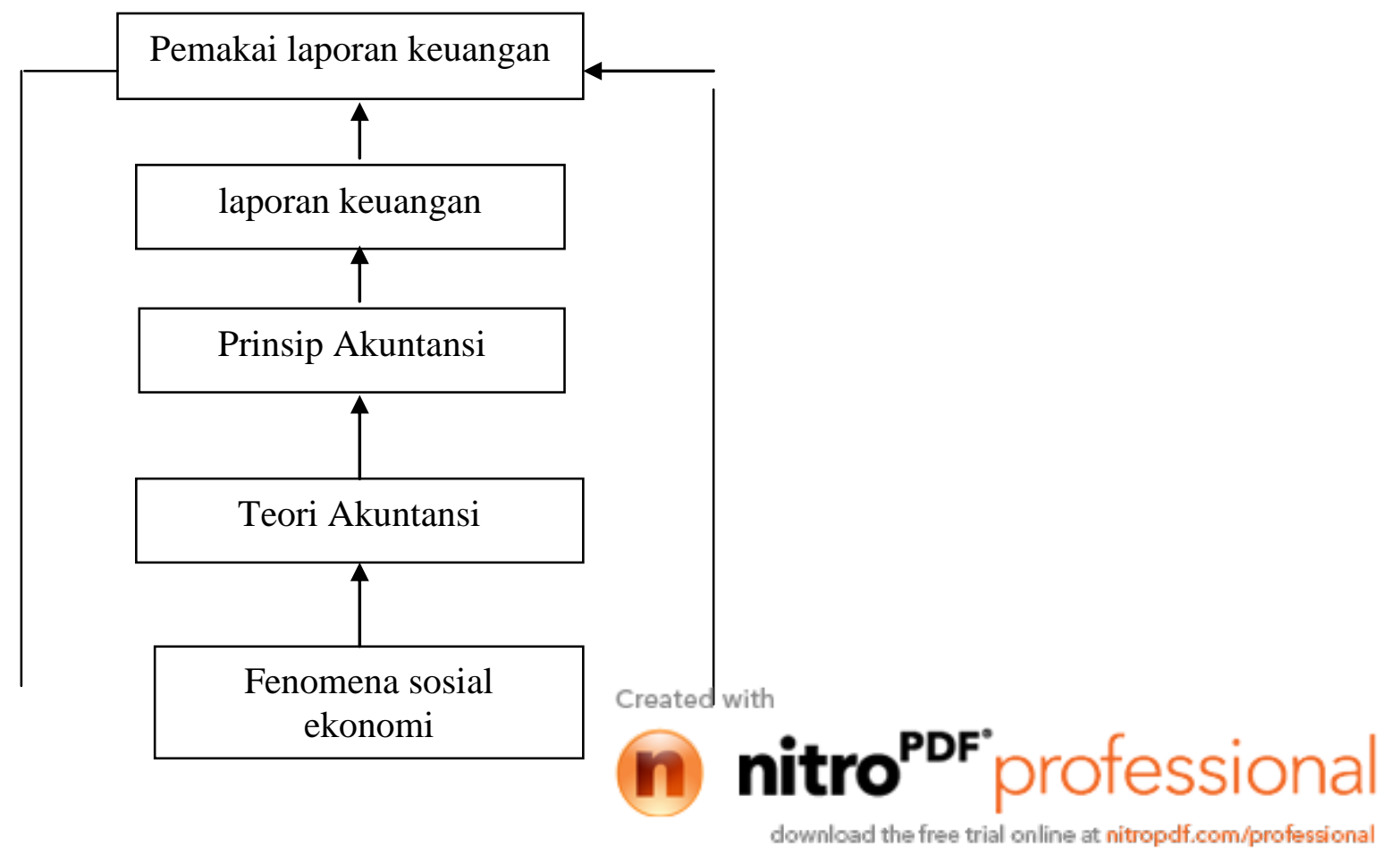


Sumber : Harahap $(1997,59)$

Sehingga dapat kita disimpulkan bahwa struktur teori akuntansi konvensional lahir dari masyarakat Amerika dengan sistem ekonomi kapitalisme dengan berbagai sifat dan sistem sosial yang dimilikinya seperti sistem demokrasi, liberalisme, sekularisme dan persaingan yang dipengaruhi dan didasari atas nilai-nilai rasional, kebebasan individu, dan nilai materi akan membawa pengaruh bagi postulat, prinsip dasar dan teknik akuntansi yang berlaku, sebagaimana bisa dilihat pada elemen-elemen dalam hirarki dapat digambarkan dibawah ini:

Gambar 2: Hirarki Elemen Struktur Teori Akuntansi konvensional Sumber : Belkaoui $(1999,133)$

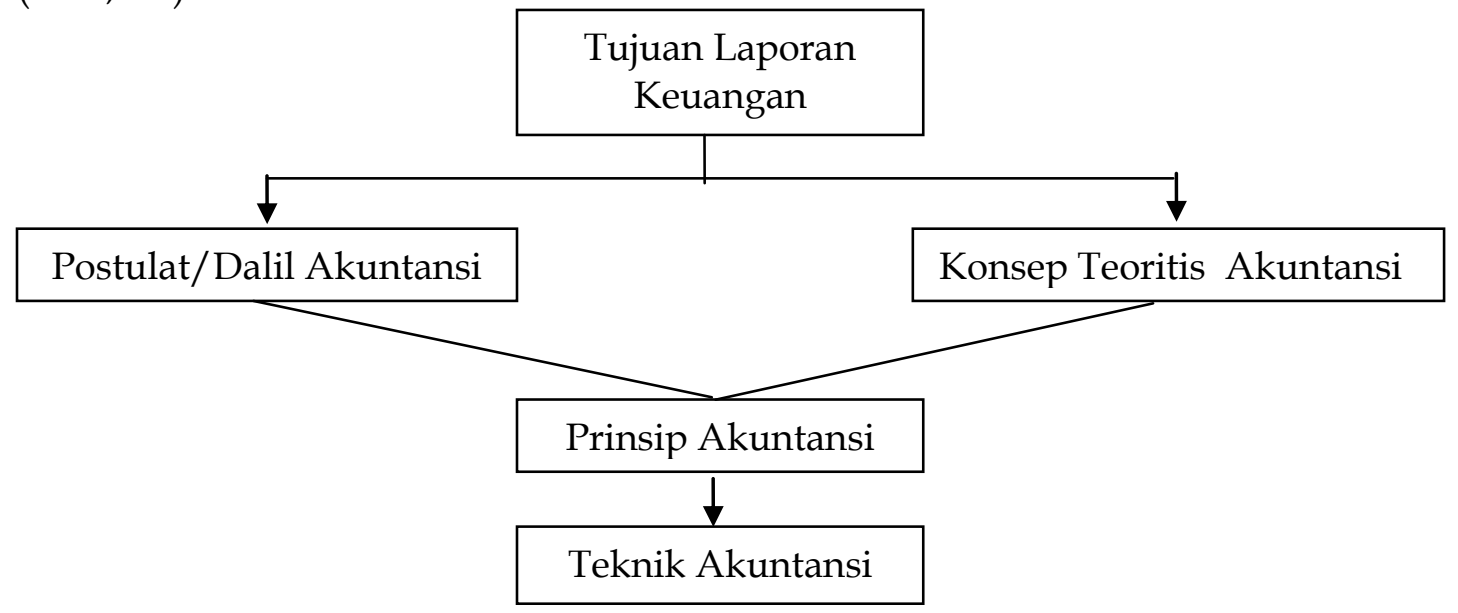

Dari hirarki di atas dapat kita lihat elemen-elemen yang membentuk akuntansi yaitu;

1. Rumusan tentang tujuan laporan keuangan .

2. Rumusan tentang postulat/dalil dan konsep teoritis yang berhubungan dengan asumsiasumsi dan sifat akuntansi.

3. Rumusan prinsip akuntansi utama yang berdasarkan pada postulat dan konsep teoritis tadi.

4. Teknik akuntansi yang dirumuskan dari prinsip akuntansi utama . 
Dengan mengacu pada Belkaoui (1999) maka, elemen-elemen dalam struktur teori akuntansi didefinisikan sebagai berikut:

a. Postulat/Dalil Akuntansi adalah pernyataan atau aksioma yang terbukti dengan sendirinya, yang diterima umum karena kesesuaiannya dengan laporan keuangan, yang menggambarkan lingkungan ekonomi, politik, sosial, dan hukum dari suatu lingkungan di mana akuntansi itu beroperasi.

b. Konsep teoritis akuntansi adalah pernyataan yang dapat membuktikan kebenarannya sendiri atau juga disebutkan aksioma yang sudah diterima umum karena kesesuaiannya dengan tujuan laporan keuangan yang menggambarkan sifat-sifat entitas akuntansi yang berperan dalam ekonomi bebas yang ditandai oleh adanya pengakuan adanya kepemilikan pribadi atas kekayaan.

c. Prinsip akuntansi adalah peraturan umum, yang dijabarkan dari tujuan laporan keuangan, atau konsep teoritis akuntansi yang menjadi dasar dalam pengembangkan teknik akuntansi.

d. Teknik Akuntansi adalah peraturan-peraturan umum, yang dijabarkan dari prinsip akuntansi, yang mengatur tentang bagaimana perlakuan terhadap transaksi-transaksi atas kejadian-kejadian tertentu yang dialami suatu entity ( Belkaoui, 1999:132-4).

Dari definisi elemen-elemen struktur teori akuntansi di atas akan kita perjelas sebagai berikut:

\section{Tujuan Laporan Keuangan dan Pengaruh Kapitalisme}

Tujuan laporan keuangan mempunyai kedudukan tertinggi sebagai bagian dari kerangka acuan konseptual, yang akan membawa konsekuensi kepada pembentukan standar dan praktek akuntansi (Suwaldiman, 2000:68). Tujuan laporan keuangan ini tidak lepas dari pengaruh kondisi ekonomi, hukum, politik, dan lingkungan sosial dimana akuntansi itu dipraktekkan. Namun demikian dalam penetapan tujuan keuangan ini banyak berorientasi pada tujuan laporan keuangan yang ditetapkan oleh FASB Amerika Serikat yang sarat dengan nilai-nilai kapitalisme.

Berikut ini akan dijelaskan mengenai tujuan laporan keuangan secara umum berdasarkan manfaat informasi keuangan sebagai berikut: 
a) Menyediakan informasi yang menyangkut posisi keuangan, kinerja serta perubahan posisi keuangan suatu perusahaan yang bermanfaat bagi sejumlah besar pemakai dalam pengambilan keputusan ekonomi.

Dalam paragraf ke-12 Framework For The Preparation and Presentation Of Financial Statements, dari IASC menetapkan tujuan pelaporan keuangan sehubungan dengan dengan fungsi laporan keuangan untuk membantu dalam pengambilan keputusan ekonomi, seperti dikutip dalam PSAK 2002 (2002, 4), menyatakan:

The objective of Financial statements is to provide information about the financial position, performance and changes in financial position of an enterprise that is useful to a wide range of users in making economic decisions (IASC 1994, paragraf 12).

Jelas bahwa tujuan laporan keuangan adalah untuk menyediakan informasi yang bermanfaat bagi pengambil keputusan ekonomi terutama sekali kreditor dan investor. Laporan keuangan diharapkan dapat memberikan informasi yang bermanfaat dalam pengambilan keputusan investasi, kredit dan keputusan lainnya secara rasional.

b) Memberikan informasi yang berguna untuk mengevaluasi prospek arus kas. Sehubungan dengan informasi mengenai aliran kas perusahaan, IASC menetapkan tujuan pelaporan keuangan sebagai berikut:

Financial statements prepared for this purpose meet the common needs of most users. However financial statements do not provide all the information that users may need to make economic decisions since they largely portray the financial effects of past events and do not necessarily provide non-financial information (IASC 1994, paragraf 13).

Pada prinsipnya dalam kaitannya dengan laporan keuangan harus dapat memberikan informasi masa lampau dan tidak diwajibkan memberikan informasi keuangan.

c) Memberikan informasi mengenai sumber-sumber ekonomi perusahaan, klaim terhadap sumber-sumber tersebut, dan perubahannya.

Dalam hal tujuan laporan keuangan berkaitan sumberdaya , IASC menyatakan:

Financial statements also show the results of the stewardship of management, or the accountability of management for the resources entrusted to it. Those users who wish to assess the stewardship or accountability of management do so in order that they may make economic decisions; these decisions may include, for example, whether to hold or sell their investment in the enterprise or whether to reappoint or replace the management (IASC 1994, paragraf 14).

Tujuan tersebut dirinci lagi menjadi lima sub bab tujuan yang masing-masing adalah informasi yang berhubungan dengan: 
(1) Sumber-sumber ekonomi, kewajiban, dan modal milik.

(2) Kinerja dan laba perusahaan.

(3) Likuiditas, solvabilitas dan aliran dana.

(4) Pertanggungjawaban dan kinerja manajemen.

(5) Penjelasan dan interprestasi manajemen.

Sedangkan tujuan laporan keuangan menurut PSAK 2002 yang mengadopsi dari IASC dalam paragraf ke 12, 13 dan 14 dinyatakan bahwa:

(a) Tujuan laporan keuangan adalah menyediakan informasi yang menyangkut posisi keuangan, kinerja serta perubahan posisi keuangan suatu perusahaan yang bermanfaat bagi sejumlah besar pemakai dalam pengambilan keputusan ekonomi.

(b) Laporan keuangan yang disusun untuk tujuan ini memenuhi kebutuhan bersama sebagian besar pemakai. Namun demikian, laporan keuangan tidak menyediakan semua semua informasi yang mungkin dibutuhkan pemakai dalam pengambilan keputusan ekonomi secara umum menggambarkan pengaruh keuangan dari kejadian masa lalu, dan tidak tidak diwajibkan menyediakan informasi non keuangan.

(c) Laporan keuangan juga menunjukkan apa yang telah dilakukan manajemen (stewardship), atau pertanggungjawaban manajemen atau sumber daya yang dipercayakan kepadanya. Pemakai yang ingin menilai apa yang telah dilakukan atau pertanggungjawaban manajemen berbuat demikian, agar mereka dapat membuat keputusan ekonomi. Keputusan ini mungkin mencakup, misalnya, keputusan untuk menahan atau menjual investasi mereka dalam perusahaan atau keputusan untuk mengangkat kembali atau mengganti manajemen.

Dari pernyataan di atas tampak jelas bahwa implementasi dari laporan keuangan diturunkan dari ideologi kapitalis yang mencerminkan, pertama, nilai-nilai rasional sehingga tujuan laporan keuangan yang disampaikan dalam PSAK secara jelas bahwa informasi dalam laporan keuangan tersebut ditujukan untuk pemegang saham dan kreditor, yang dinotasikan dalam kata-kata "sebagian besar". Dari informasi dalam laporan keuangan tersebut digunakan untuk tujuan pengambilan keputusan ekonomi dan pertanggungjawaban manajemen atas penggunaan yang dipercayakan kepadanya.

Kedua, Sesuai dengan tujuannya laporan keuangan digunakan dalam menetapkan keputusan ekonomik yang bertujuan maksimalisasi keuntungan dengan menekan biaya sekecilkecilnya, sesuai dengan karakteristik nilai materi. Di mana konsep ini menganggap upah buruh sebagai biaya. Padahal buruh di pabrik nerupakan komponen yang sangat vital dalam 
kaitannya dengan produksi. Sangatlah riskan sekali jika akuntansi kapital ini hanya mementingkan pemilik usaha, sehingga selalu timbul konflik antara pemilik dengan buruh.

Ketiga, keputusan-keputusan ekonomi yang diutamakan oleh pengguna informasi berdasarkan posisi keuangan, kinerja serta perubahan posisi keuangan sebagai prioritas, dengan mengesampingkan aspek-aspek lain, yaitu aspek sosial dan accountability, di mana dalam nilai rasional kepentingan moral maupaun agama diabaikan untuk tujuan-tujuan individu dalam rangka pemenuhan nafsu pribadi, di sinilah muncul nilai kebebasan bahwa setiap individu mempunyai kebebasan dalam bertindak dan berperilaku di bidang ekonomi, sehingga individu bebas menggunakan informasi keuangan yang ada untuk tujuan pribadinya, sehingga diperoleh banyak keuntungan yang berlipat karena mengusai informasi, hal ini sesuai dengan pemupukan materi yang mengutamakan bertumpuknya kekayaan sehingga lingkungan sosial masyarakat terabaikan.

\section{KESIMPULAN}

Semangat kapitalistik yang mengarahkan rasionalitas atas sejumlah perilaku masyarakat merupakan proporsi penting yang dominan dalam sejumlah konsep dasar teori akuntansi. Sehingga semangat kapitalistik sebagai ideologi dan kekuatan sosial yang sedemikian kuat akan memiliki hubungan dan pengaruh yang signifikan terhadap perkembangan akuntansi, yang kita kenal dengan Teori Akuntansi Positif (Positive Accounting Theory atau Mainstream Accounting Theory).

Kekuatan sosial didefinisikan oleh Kam $(1990,3)$ sebagai energi manusia yang berakar dalam motif-motif individu, yang dikoalisikan pada manifestasi kolektif dari kekuatan dan merupakan kekuatan sosial interaktif kesatuan bisnis, di mana Kam menyebutkan salah satunya adalah spirit kapitalistik. Perkembangan akuntansi melalui tatabuku berpasangan sangat terkait dengan semangat kapitalistik sebagai kekuatan pendorong yang memotivasi dan mengarahkan manusia membentuk kesatuan bisnis untuk meraih maksimalisasi laba optimum.

Walaupun akuntansi memang dapat digunakan untuk berbagai jenis organisasi, baik profit maupun nonprofit dan dalam berbagai sistem sosial, baik kapitalisme, sosialisme, atau yang lain, namun terminologi spirit kapitalistik sendiri telah merambah jauh melintasi perspektif yang lebih luas daripada sekedar bentuk-bentuk sistem ekonomi politik . 


\section{DAFTAR PUSTAKA}

Andreski, Stanislav. 1996. Max Weber : Kapitalisme, Birokrasi dan Agama. terj. Hartono. Yogyakarta: Tiara Wacana.

an-Nabhani, Taqyuddin. 1996. Membangun Sistem Ekonomi Alternatif; Perspektif Islam. terj. Moh.Maghfur Wachid. Surabaya: Risalah Gusti.

Belkaoui, Ahmed. 1999. Accounting Theory (Teori Akuntansi). Jilid 1. terj. Budhi Pujiharto. Yogyakarta:AK Group.

Belkaoui, Ahmed. 2000. Teori Akuntansi. Buku 1. terj. Marwata, dkk. Jakarta: Salemba Empat.

Fakih, Mansour. 2002. Runtuhnya Teori Pembangunan dan Globalisasi. Yogyakarta: Pustaka Pelajar.

Harahap, Sofyan S. 1997. Akuntansi Islam. Jakarta: Bumi Aksara.

Harahap, Sofyan S. 2001. Menuju Perumusan Teori Akuntansi Islam. Jakarta: Pustaka Quantum.

Kam, Vernon. 1990. Accounting Theory. 2nd edition. New York: John Wiley and Son.

Khan, Mohsin S. dan Abbas Mirakhor. 1989. The Framework and Practice of Islamic Banking. Journal of Islamic Banking and Finance 6 (1): 22-44.

Mathews, MR dan MHB Perera. 1993. Accounting Theory and Development. Melbourne: Thomas Nelson Australia.

Muhammad. 2002. Penagntar Akuntansi Syariah. Jakarta: Salemba Empat.

Syari'ati, Ali. 1996. Humanisme: Antara Islam dan Mazhab Barat. terj. Afif Muhammad. Bandung: Pustaka Hidayah.

Triyuwono, Iwan. 1996. Teori Akuntansi Berhadapan Dengan Nilai-Nilai Islam. Ulumul Qur'an VI (5): 44-61

Triyuwono, Iwan. 2000. Akuntansi Syari'ah: Paradigma Baru dalam Wacana akuntansi". Seminar Nasional Ekonomi Islam dan Kongres Kelompok Studi Ekonomi Islam dengan Tema "Reposisi dan Revitalisasi Ekonomi Islam serta Strategi Pengembangannya di Indonesia, diselenggarakan oleh Kelompok Studi Ekonomi Islam Sie Rohani Islam Fakultas Ekonomi Universitas Diponegoro 11-13 Mei 2000. 